\title{
Productive performance of Mexican Creole chickens from hatching to 12 weeks of age fed diets with different concentrations of metabolizable energy and crude protein
}

\author{
Miguel Ángel Matus-Aragón', Fernando González-Cerón², Josafhat Salinas-Ruiz ${ }^{3}$, \\ Eliseo Sosa-Montes ${ }^{2}$, Arturo Pro-Martínez ${ }^{1}{ }^{1 *}$, Omar Hernández-Mendo ${ }^{1}$, \\ Juan Manuel Cuca-García ${ }^{1}$, and David Jesús Chan-Díaz ${ }^{4}$
}

\footnotetext{
* Corresponding Author: Arturo Pro-Martínez Tel: +52-01-55-5804-5900 (1707),

Fax: +52-01-59-5952-0203,

E-mail: aproma@colpos.mx

'Program of Animal Science, College of Postgraduates, Campus Montecillo, Texcoco, State of Mexico 56230, Mexico

2 Department of Animal Science, Chapingo

Autonomous University, Chapingo, State of Mexico 56230, Mexico

${ }^{3}$ College of Postgraduates Campus Cordoba,

Cordoba, Veracruz 94946, Mexico

${ }^{4}$ Trouw Nutrition Mexico, S.A. de C.V.,

Zapopan, Jalisco 45150, Mexico

\section{ORCID}

Miguel Ángel Matus-Aragón

https://orcid.org/0000-0002-0696-9176 Fernando González-Cerón

https://orcid.org/0000-0002-2417-6700

Josafhat Salinas-Ruiz

https://orcid.org/0000-0003-4465-325X

Eliseo Sosa-Montes

https://orcid.org/0000-0003-2027-8168 Arturo Pro-Martínez

https://orcid.org/0000-0003-3237-4894

Omar Hernández-Mendo

https://orcid.org/0000-0003-0756-7387

Juan Manuel Cuca-García

https://orcid.org/0000-0002-3961-972X

David Jesús Chan-Díaz

https://orcid.org/0000-0002-5620-0293
}

Submitted Sept 29, 2020; Revised Nov 2, 2020; Accepted Dec 4, 2020
Objective: The study aimed to evaluate the productive performance, carcass yield, size of digestive organs and nutrient utilization in Mexican Creole chickens, using four diets with different concentrations of metabolizable energy ( $\mathrm{ME}, \mathrm{kcal} / \mathrm{kg}$ ) and crude protein $(\mathrm{CP}, \%)$. Methods: Two hundred thirty-six chickens, coming from eight incubation batches, were randomly distributed to four experimental diets with the following ME/CP ratios: 3,000/20, $2,850 / 19,2,700 / 18$ and 2,550/17. Each diet was evaluated with 59 birds from hatching to 12 weeks of age. The variables feed intake (FI), body weight gain (BWG), feed conversion (FC), mortality, carcass yield, size of digestive organs, retention of nutrients, retention efficiency of gross energy (GE) and $\mathrm{CP}$, and excretion of $\mathrm{N}$ were recorded. Data were analyzed as a randomized block design with repeated measures using the GLIMMIX procedure of SAS, with covariance AR (1) and adjustment of degrees of freedom (KendwardRoger), the adjusted means were compared with the least significant difference method at a significance level of 5\%.

Results: The productive performance variables BWG, mortality, carcass yield, fat and GE retention and excretion of $\mathrm{N}$ were not different $(\mathrm{p}>0.05)$ due to the diet effect. In the 3,000/20 diet, the chickens had lower values of FI, FC, crop weight, gizzard weight, retention, and retention efficiency of $\mathrm{CP}(\mathrm{p}<0.05)$ than the chickens of the 2,550/17 diet.

Conclusion: The Mexican Creole chickens from hatching to 12 weeks of age can be feed with a diet with 2,550 kcal ME and $17 \% \mathrm{CP}$, without compromising productive parameters (BWG, mortality, carcass yield) but improving retention and retention efficiency of CP.

Keywords: Apparent Metabolizable Energy; Carcass Yield; Crude Protein; Mexican Creole Chickens; Nutrient Utilization; Productive Performance

\section{INTRODUCTION}

The production of Mexican Creole chickens provides animal protein and income to families in rural communities [1]. Birds of this genotype can survive and produce meat and eggs even with inadequate nutrition and unsanitary conditions [2]. Although Mexican Creole birds are an important genetic resource, they have been little studied and their nutritional requirements such as metabolizable energy (ME) and crude protein $(\mathrm{CP})$ are unknown. Studying the retention efficiency of ME and CP is key in animal nutrition given that those nutrients represent approximately $90 \%$ of the total cost of the diet in domestic chickens [3]. Additionally, an imbalance in these components in the diet can retard growth [4] and reduce economic returns. 
Feed intake (FI) in chickens is influenced by the concentration of ME in the diet. When diets are low in ME, FI increases. But if the feed is bulky and exceeds the storage capacity of the digestive system, the chickens may not consume adequate amounts of nutrients [4]. On the contrary, if the concentration of $\mathrm{ME}$ is high in relation to $\mathrm{CP}$ and amino acids, fat deposition can increase $[5,6]$ and body weight gain (BWG) can be compromised [4]. Excess $\mathrm{CP}$ in diet can results in excess of $\mathrm{N}$ excretion in litter house causing skin dermatitis, footpad lesions and hock burns and ammonia emission [7].

Although there are few studies on the feeding of the Mexican Creole chickens using diets with different concentrations of $\mathrm{ME}$ and $\mathrm{CP}$, the specific nutritional needs of this genotype of birds are unknown. Some examples of these studies are: Segura-Correa et al [8], used a diet with 3,098 kcal ME/kg and $21 \% \mathrm{CP}$ from 0 to 21 days of age and a diet with $2,998 \mathrm{kcal}$ $\mathrm{ME} / \mathrm{kg}$ and $19 \% \mathrm{CP}$, from 22 to 49 days of age. Mata-Estrada et al [1], used diets with 3,000 kcal ME/kg and 19\% CP from 0 to 18 days and a diet with $2,800 \mathrm{kcal} \mathrm{ME} / \mathrm{kg}$ and $18 \% \mathrm{CP}$ from 19 to 177 days of age. Therefore, the aim of this study was to evaluate the productive performance, carcass yield, size of digestive organs and nutrient utilization in Mexican Creole chickens, using four diets with different concentrations of $\mathrm{ME}$ and $\mathrm{CP}$, in order to have an estimation of the requirements of $\mathrm{ME}$ and $\mathrm{CP}$ in this genotype of birds.

\section{MATERIALS AND METHODS}

The experiment was carried out from January to July 2019, in the poultry facilities of the Colegio de Postgraduados, Campus Montecillo, in Texcoco, State of Mexico, Mexico, at coordinates $19^{\circ} 29^{\prime} \mathrm{N}, 98^{\circ} 54^{\prime} \mathrm{W}$, and an altitude of $2,247 \mathrm{~m}$.

\section{Chickens and management}

Two hundred thirty-six straight-run chicks, coming from eight incubation batches, were randomly distributed to four experimental diets. Each diet was evaluated with 59 birds ( 30 males and 29 females) from hatching to 12 weeks of age. At hatching, the chickens were individually identified with marks on the interdigital membranes, according to what was established by Storey [9]. From hatching to eight weeks of age, the birds were housed in electric brooders $(0.40 \times 1.10 \times 0.40 \mathrm{~m})$ with an initial temperature of $32^{\circ} \mathrm{C}$, which was gradually reduced to $28^{\circ} \mathrm{C}$. Later and until 12 weeks of age, the birds were housed in pens of $1.0 \times 1.5 \times 1.0 \mathrm{~m}$, with a bed of wood shavings and an average room temperature of $24^{\circ} \mathrm{C}$. Water and feed were provided ad libitum throughout the experimental period. The chickens were cared according to the guidelines established by the Animal Welfare Committee of the Colegio de Postgraduados, Campus Montecillo, State of Mexico, Mexico.

\section{Experimental diets}

Four diets were formulated with different concentrations of $\mathrm{ME}$ and CP (Table 1), maintaining constant ratios of 150 $\mathrm{ME}(\mathrm{kcal} / \mathrm{kg}$ ) and CP (\%): 3,000/20; 2,850/19; 2,700/18; and $2,550 / 17$. The ingredients used in the formulation of the diets were analyzed with the NIRS foss model DS2500 equipment (Hilleroed, Denmark). Requirements of the essential amino acid, calcium and phosphorus were met according to the NRC [10] for broilers.

\section{Productive performance}

The productive performance variables: FI (g/chicken), BWG (g/chicken), feed conversion (FC; g/g) were recorded weekly, and mortality daily.

\section{Carcass yield}

At 12 weeks of age, the weight of the carcass and its parts were determined, as well as the corresponding yields, according to Van Harn et al [7]. In each of the eight blocks (incubation batches), two birds were randomly selected per experimental diet, in total 16 birds per diet were obtained (eight males and eight females). Chickens were slaughtered according to the Official Mexican Standard NOM-033-SAG/ ZOO-2014 [11], using a stunner electric knife followed by slaughtering and bleeding.

\section{Digestive organs and abdominal fat}

In addition to carcass yield variables data were also collected on relative empty weight of the crop, proventriculus, gizzard, small intestine and caeca, relative weight of liver, pancreas and abdominal fat, and relative length of the small intestine and caeca, according to Mera-Zúñiga et al [12]. These variables were expressed in relation to body weight.

\section{Nutrient utilization}

At 12 weeks of age, the chemical composition (moisture, dry matter, $\mathrm{CP}$, fat, ash and gross energy [GE]), nutrient retention (CP, fat, and GE), GE and $\mathrm{CP}$ retention efficiency were determined for the whole-body of chickens, as well as excretion of $\mathrm{N}$, according to the methodology described by Aletor et al [5]. Two birds were randomly selected per experimental diet in each block, in total 16 birds per diet (eight males and eight females).

The birds were subjected to a 12-hour of fast before they were slaughtered. The slaughter of the birds was performed using a stunner electric knife and cervical dislocation, while avoiding loss of blood. The whole-body of each chicken was frozen at $-20^{\circ} \mathrm{C}$. Subsequently, these were thawed and placed in an autoclave for 5 hours at $110^{\circ} \mathrm{C}$ and a pressure of $1 \mathrm{~atm}$. Finally, each chicken body was individually placed in an industrial blender for 10 minutes and a sample of $300 \mathrm{~g}$ of ground meat was lyophilized and analyzed for chemical 
Table 1. Composition (\%) and calculated analysis of the experimental diets used

\begin{tabular}{|c|c|c|c|c|}
\hline \multirow{2}{*}{ Items } & \multicolumn{4}{|c|}{ ME/CP concentrations of diets } \\
\hline & $3,000 / 20$ & $2,850 / 19$ & $2,700 / 18$ & $2,550 / 17$ \\
\hline \multicolumn{5}{|l|}{ Ingredients (\%) } \\
\hline Soybean meal & 24.037 & 19.827 & 14.899 & 14.154 \\
\hline Yellow corn DDGS & 6.000 & 6.000 & 6.000 & 5.701 \\
\hline Canola meal & 6.000 & 6.000 & 6.000 & 5.701 \\
\hline Calcium carbonate & 1.317 & 1.328 & 1.332 & 1.264 \\
\hline Dicalcium phosphate & 0.910 & 0.913 & 0.907 & 0.861 \\
\hline Mineral-vitamin premix ${ }^{1)}$ & 0.502 & 0.502 & 0.502 & 0.476 \\
\hline Sodium chloride & 0.307 & 0.263 & 0.211 & 0.200 \\
\hline DL-Methionine & 0.117 & 0.139 & 0.165 & 0.157 \\
\hline \multicolumn{5}{|l|}{ Calculated analysis (\%) } \\
\hline Metabolizable energy (kcal/kg) & $3,000.00$ & $2,850.00$ & $2,700.00$ & $2,550.00$ \\
\hline Crude protein & 20.00 & 19.00 & 18.00 & 17.00 \\
\hline Energy:protein ratio & 150.00 & 150.00 & 150.00 & 150.00 \\
\hline Dry matter & 88.80 & 88.60 & 88.60 & 88.80 \\
\hline Crude fiber & 3.20 & 3.70 & 4.50 & 6.20 \\
\hline Calcium & 1.00 & 1.00 & 1.00 & 1.10 \\
\hline Available phosphorus & 0.45 & 0.45 & 0.45 & 0.44 \\
\hline Lysine & 1.08 & 1.05 & 1.05 & 1.05 \\
\hline Methionine & 0.47 & 0.40 & 0.40 & 0.41 \\
\hline Methionine+cystine & 0.80 & 0.82 & 0.80 & 0.80 \\
\hline
\end{tabular}

ME, metabolizable energy; CP, crude protein; DDGS, dried distillery grains with solubles.

1) Provided the following per kilogram of diet: vitamin $A, 12,000 \mathrm{IU}$; vitamin $D_{3}, 1,000 \mathrm{IU}$; vitamin $E, 60 \mathrm{IU}$; vitamin $\mathrm{K}, 5.0 \mathrm{mg}$; vitamin $B_{2}, 8.0 \mathrm{mg}$; vitamin $B_{12}$, 0.030 mg; pantothenic acid, $15 \mathrm{mg}$; niacin, 50 mg; folic acid, $1.5 \mathrm{mg}$; choline, 300 mg; biotin, 0.150 mg; thiamine, 3.0 mg. Fe, 50.0 mg; Zn, 110 mg; Mn, 100 mg; Cu, 12.0 mg; Se, 0.3 mg; l, 1.0 mg.

2) Oat straw was used as an inert filler in diet.

composition in order to estimate the values of nutrient retention, and retention efficiency of GE and CP. Analyzes of the chemical composition of the body were performed in triplicate, according to the AOAC [13]. The GE or heat of combustion was determined using an isoperibolic calorimeter (No. 1266, Parr instruments, Moline, IL, USA). The procedures described above to determine the chemical composition of the whole-body of the birds were also performed for a sample of 16 chickens at hatching.

Nutrient retention was estimated according to the following expression:

$\mathrm{CP}$ retained $(\mathrm{g})$

$=\mathrm{CP}$ in the whole body of the chicken at 12 weeks of age - average CP in the whole body of chicks at hatching

Likewise, fat and GE retained were calculated, substitut- ing in the previous expression, the $\mathrm{CP}$ value for the fat $(\mathrm{g})$ or $\mathrm{GE}$ (kcal) value, respectively.

The retention efficiency of GE and $\mathrm{CP}$ were calculated as follows:

$$
\begin{aligned}
& \text { GE retention efficiency }(\%)=\frac{\mathrm{kcal} \text { GE retained }}{\mathrm{kcal} \mathrm{GE} \mathrm{consumed}} \times 100 \\
& \text { CP retention efficiency }(\%)=\frac{\mathrm{g} \mathrm{CP} \text { retained }}{\mathrm{g} \mathrm{CP} \text { consumed }} \times 100
\end{aligned}
$$

Nitrogen excretion was calculated as follows:

$\mathrm{N}$ excretion $(\mathrm{g})$

$=\mathrm{N}$ consumed $-\mathrm{N}$ retained in the whole body of the chicken at 12 weeks of age 


\section{Statistical analysis}

Data were analyzed according to a randomized block design with repeated measures using the GLIMMIX procedure of SAS version 9.4 (SAS Institute, 2013) [14], AR (1) covariance structure and Kenward-Roger degrees of freedom adjustment [15]. Statistical differences were established at $\mathrm{p}<0.05$ and adjusted means were compared with the least significant difference method. For the variables of productive performance and nutrient retention efficiency, the effect of diets was studied; while for the variables of carcass yield, size of digestive organs, chemical composition of the whole-body and nutrient retention, the effects of diet and sex of the chickens, as well as their interaction, were studied.

\section{RESULTS}

\section{Productive performance}

In the period from hatching to 12 weeks of age, differences $(p<0.05)$ were detected among diets for the FI and FC variables. In contrast, BWG and mortality were not different ( $\mathrm{p}>$ $0.05)$ among the diets (Table 2). The FI was highest $(\mathrm{p}<0.05)$ in the $2,550 / 17$ and 2,700/18 diets, followed by the $2,850 / 19$ and $3,000 / 20$ treatments. Feed conversion was lower $(\mathrm{p}<0.05)$ in the 3,000/20 diet compared to the 2,700/18 and 2,550/17 diets.

\section{Carcass yield}

The diet had a significant effect $(\mathrm{p}<0.05)$ only on the weight of the wings (Table 3 ). The sex of the birds also affected ( $\mathrm{p}<$ $0.05)$ the variables studied, except for legs and thigh yield. However, there was no diet $\times$ sex interaction $(\mathrm{p}>0.05)$ for any of the variables evaluated. The weight of the wings was significantly higher $(\mathrm{p}<0.05)$ in chickens fed the diet 2,550/17 compared to the diet 3,000/20. Male chickens had higher $(\mathrm{p}<0.05)$ weight and performance in most of the variables studied, except in breast and wing yields, which were higher $(\mathrm{p}<0.05)$ in females.

\section{Digestive organs and abdominal fat}

Diets affected $(\mathrm{p}<0.05)$ the relative weight of the crop, gizzard and pancreas (Table 4$)$. Sex had an effect $(\mathrm{p}<0.05)$ on the relative empty weight of the proventriculus, gizzard and caeca, relative weight of liver and pancreas, and relative length of the small intestine and caeca. The relative weight of the crop was higher $(\mathrm{p}<0.05)$ in chickens fed diets $2,850 / 19$ and 2,550/17 compared to those fed diet 3,000/20. The relative weight of the gizzard was higher $(\mathrm{p}<0.05)$ in the chickens fed diet 2,550/17 compared to the other diets. The relative weight of the pancreas was higher $(\mathrm{p}<0.05)$ in chickens fed diet 2,550/17 compared to chickens fed diet 2,850/19. Female chickens had a greater $(\mathrm{p}<0.05)$ weight of the proventriculus,

Table 2. Cumulative productive performance of Mexican Creole chickens from hatching to 12 weeks of age fed diets with different concentrations of ME and CP

\begin{tabular}{lcccccc}
\hline \multirow{2}{*}{ Variable } & \multicolumn{3}{c}{ ME/CP concentrations of diets } & \multirow{2}{*}{ SEM } & \multirow{2}{*}{ p-value } \\
\cline { 2 - 5 } & $\mathbf{3 , 0 0 0 / 2 0}$ & $\mathbf{2 , 8 5 0 / 1 9}$ & $\mathbf{2 , 7 0 0 / 1 8}$ & $\mathbf{2 , 5 5 0 / 1 7}$ & & 71.14 \\
Feed intake (g/chick) & $3,761.43^{\mathrm{c}}$ & $4,114.92^{\mathrm{b}}$ & $4,359.07^{\mathrm{a}}$ & $4,450.11^{\mathrm{a}}$ & $<0.0001$ \\
Body weight gain (g/chick) & $1,096.54$ & $1,148.97$ & $1,133.09$ & $1,095.15$ & 34.28 & 0.6006 \\
Feed conversion (g/g) & $3.50^{\mathrm{c}}$ & $3.72^{\mathrm{bc}}$ & $3.95^{\mathrm{b}}$ & $4.14^{\mathrm{a}}$ & 0.10 & 0.0006 \\
Mortality (\%) & 8.13 & 2.58 & 10.00 & 3.33 & 7.51 & 0.1524 \\
\hline
\end{tabular}

ME, metabolizable energy; CP, crude protein; SEM, standard error of the means.

${ }^{a-c}$ Means with different superscripts within each row indicate differences $(p<0.05)$.

Table 3. Carcass yield of 12-week-old of Mexican Creole chickens fed diets with different concentrations of ME and CP

\begin{tabular}{|c|c|c|c|c|c|c|c|c|c|c|c|}
\hline \multirow{2}{*}{ Variable } & \multicolumn{4}{|c|}{$\mathrm{ME} / \mathrm{CP}$ concentrations of diets } & \multirow{2}{*}{ SEM } & \multicolumn{2}{|c|}{ Sex } & \multirow{2}{*}{ SEM } & \multicolumn{3}{|c|}{ p-value } \\
\hline & $3,000 / 20$ & $2,850 / 19$ & $2,700 / 18$ & $2,550 / 17$ & & Male & Female & & Diet & Sex & Dietxsex \\
\hline Body weight (g) & $1,061.39$ & $1,151.83$ & $1,116.80$ & $1,158.46$ & 38.19 & $1,250.31^{a}$ & $993.93^{b}$ & 27.12 & 0.0710 & $<0.0001$ & 0.5700 \\
\hline Carcass weight (g) & 693.33 & 754.09 & 725.94 & 767.62 & 27.97 & $839.02^{a}$ & $631.47^{b}$ & 19.78 & 0.1370 & $<0.0001$ & 0.7940 \\
\hline Carcass yield (\%) & 65.32 & 65.47 & 65.00 & 66.26 & 1.24 & $67.10^{\mathrm{a}}$ & $63.53^{b}$ & 0.89 & 0.9250 & 0.0026 & 0.5000 \\
\hline Breast weight $(\mathrm{g})$ & 167.56 & 173.95 & 174.44 & 186.86 & 8.38 & $191.66^{\mathrm{a}}$ & $159.74^{b}$ & 5.22 & 0.1240 & 0.0002 & 0.6830 \\
\hline Breast yield (\%) & 24.17 & 23.07 & 24.03 & 24.34 & 0.67 & $22.84^{b}$ & $25.30^{a}$ & 0.47 & 0.1010 & 0.0012 & 0.4570 \\
\hline Leg weight (g) & 106.03 & 119.24 & 109.32 & 121.41 & 4.45 & $131.34^{\mathrm{a}}$ & $96.66^{\mathrm{b}}$ & 3.18 & 0.5710 & $<0.0001$ & 0.6970 \\
\hline Leg yield (\%) & 15.29 & 15.81 & 15.06 & 15.82 & 0.29 & 15.65 & 15.31 & 0.20 & 0.3300 & 0.3180 & 0.9260 \\
\hline Thigh weight (g) & 107.36 & 119.65 & 114.18 & 121.15 & 6.72 & $131.52^{\mathrm{a}}$ & $99.66^{\mathrm{b}}$ & 4.80 & 0.2040 & 0.0002 & 0.7370 \\
\hline Thigh yield (\%) & 15.48 & 15.87 & 15.73 & 15.78 & 1.04 & 15.68 & 15.78 & 0.73 & 0.9170 & 0.5140 & 0.8140 \\
\hline Wings weight (g) & $87.14^{b}$ & $97.03^{\mathrm{ab}}$ & $91.00^{\mathrm{ab}}$ & $98.02^{a}$ & 2.95 & $104.05^{\mathrm{a}}$ & $82.55^{b}$ & 2.07 & 0.0380 & $<0.0001$ & 0.8470 \\
\hline Wings yield (\%) & 12.57 & 12.87 & 12.54 & 12.77 & 0.24 & $12.40^{b}$ & $13.07^{a}$ & 0.17 & 0.9180 & 0.0260 & 0.5540 \\
\hline
\end{tabular}

$\mathrm{ME}$, metabolizable energy; $\mathrm{CP}$, crude protein; SEM, standard error of the means.

${ }^{a, b}$ Means with different superscripts within each row indicate differences $(p<0.05)$. 
Table 4. Organs size of 12-week-old of Mexican Creole chickens fed diets with different concentrations of ME and CP

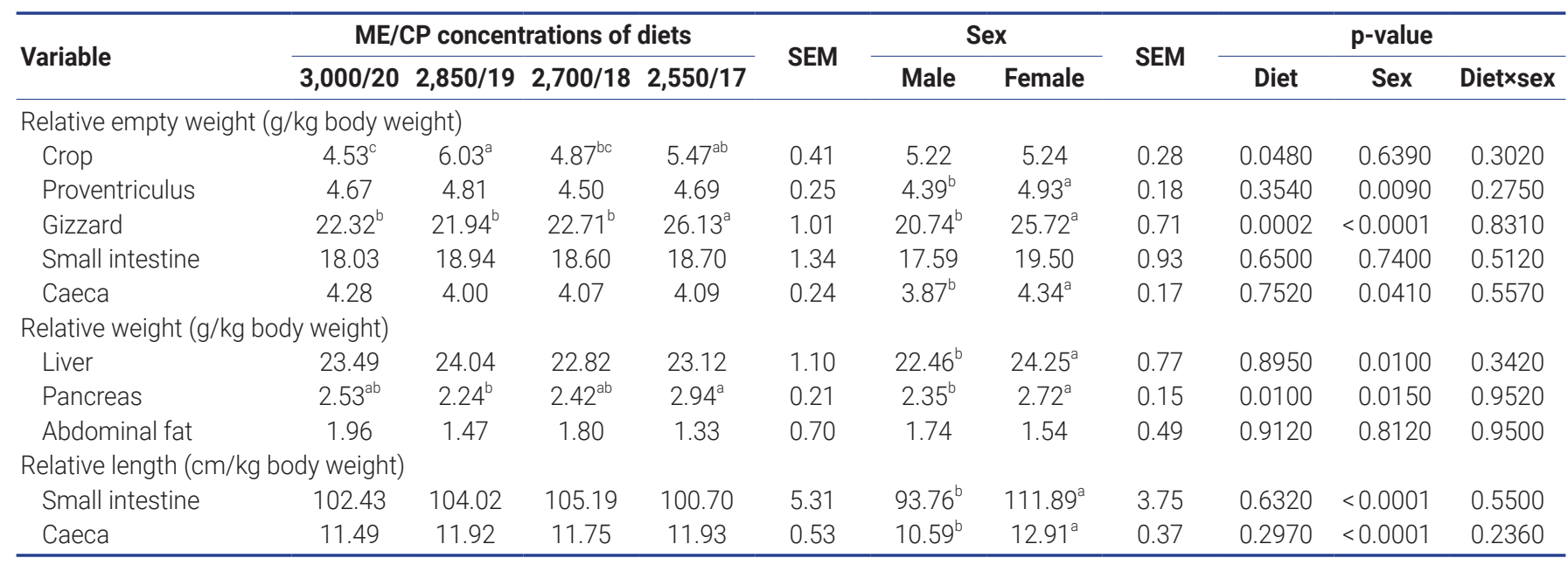

$\mathrm{ME}$, metabolizable energy; $\mathrm{CP}$, crude protein; SEM, standard error of the means.

${ }^{a-c}$ Means with different superscripts within each row indicate differences $(p<0.05)$.

gizzard, caeca, liver and pancreas, as well as a greater length of the small intestine and caeca, compared to male chickens.

\section{Nutrient utilization}

Chemical composition of the whole-body of the chickens was not affected ( $p>0.05)$ by diet, sex or the interaction (Table $5)$. Diet had a significant effect $(\mathrm{p}<0.05)$ on $\mathrm{CP}$ retention, and sex affected $(\mathrm{p}<0.05) \mathrm{CP}$ and fat retention (Table 6). Chickens fed 3,000/20 diet had lower $(\mathrm{p}<0.05)$ CP retention compared to the other three diets, and male chickens had higher $(\mathrm{p}<$ $0.05) \mathrm{CP}$ and fat retention than female chickens.

A lower $(\mathrm{p}<0.05) \mathrm{CP}$ retention efficiency was observed in chickens fed diet 3,000/20 compared to the other diets (Table
7). In contrast, the GE retention efficiency was lower $(\mathrm{p}<0.05)$ in the chickens fed the two diets with lower levels of ME and CP $(2,700 / 18$ and 2,550/17). Nitrogen excretion tended to be lower ( $\mathrm{p}<0.0961$ ) in chickens fed diet $2,550 / 17$ compared to those on the diet $3,000 / 20$, but differences were not statistically significant.

\section{DISCUSSION}

The Mexican Creole chickens are an unexplored genetic resource, so most of the variables evaluated in this study were compared with the results of investigations carried out in Creole and commercial chickens.

Table 5. Whole-body chemical composition of 12-week-old of Mexican Creole chickens fed diets with different concentrations of ME and CP

\begin{tabular}{|c|c|c|c|c|c|c|c|c|c|c|c|}
\hline \multirow{2}{*}{ Variable } & \multicolumn{4}{|c|}{ ME/CP concentrations of diets } & \multirow{2}{*}{ SEM } & \multicolumn{2}{|c|}{ Sex } & \multirow{2}{*}{ SEM } & \multicolumn{3}{|c|}{ p-value } \\
\hline & $3,000 / 20$ & $2,850 / 19$ & $2,700 / 18$ & $2,550 / 17$ & & Male & Female & & Diet & Sex & Diet×sex \\
\hline Moisture (g/kg) & 658.90 & 647.37 & 630.17 & 639.37 & 20.71 & 633.15 & 654.75 & 16.36 & 0.7087 & 0.2433 & 0.8303 \\
\hline $\mathrm{DM}(\mathrm{g} / \mathrm{kg})$ & 341.10 & 352.63 & 369.83 & 360.63 & 20.71 & 366.85 & 345.25 & 16.36 & 0.7087 & 0.2433 & 0.8303 \\
\hline $\mathrm{CP}(\mathrm{g} / \mathrm{kg})$ & 220.78 & 232.56 & 249.95 & 246.69 & 12.75 & 243.88 & 231.12 & 9.97 & 0.2514 & 0.2700 & 0.4473 \\
\hline Fat $(\mathrm{g} / \mathrm{kg})$ & 64.94 & 59.27 & 60.69 & 52.51 & 8.40 & 63.76 & 54.94 & 6.30 & 0.7084 & 0.2753 & 0.3627 \\
\hline Ash (g/kg) & 29.73 & 28.20 & 31.06 & 31.00 & 3.86 & 31.84 & 28.15 & 2.98 & 0.9326 & 0.3000 & 0.2722 \\
\hline GE (kcal/kg of DM) & $4,786.01$ & $4,972.10$ & $4,735.51$ & $4,564.85$ & 117.75 & $4,757.56$ & $4,771.67$ & 82.38 & 0.151 & 0.907 & 0.3216 \\
\hline
\end{tabular}

ME, metabolizable energy; CP, crude protein; SEM, standard error of the means; DM, dry matter; GE, gross energy.

Table 6. Nutrient retention in the whole body of 12-week old of Mexican Creole chickens fed diets with different concentrations of ME and CP

\begin{tabular}{|c|c|c|c|c|c|c|c|c|c|c|c|}
\hline \multirow{2}{*}{ Variable } & \multicolumn{4}{|c|}{ ME/CP concentrations of diets } & \multirow{2}{*}{ SEM } & \multicolumn{2}{|c|}{ Sex } & \multirow{2}{*}{ SEM } & \multicolumn{3}{|c|}{ p-value } \\
\hline & $3,000 / 20$ & $2,850 / 19$ & $2,700 / 18$ & $2,550 / 17$ & & Male & Female & & Diet & Sex & Dietxsex \\
\hline $\mathrm{CP}$ retention (g/chick) & $191.57^{b}$ & $267.23^{\mathrm{a}}$ & $288.37^{a}$ & $256.97^{\mathrm{a}}$ & 14.83 & $289.76^{\mathrm{a}}$ & $212.32^{b}$ & 9.94 & 0.0018 & $<0.0001$ & 0.3220 \\
\hline Fat retention (g/chick) & 56.98 & 68.45 & 66.33 & 53.51 & 8.31 & $73.66^{\mathrm{a}}$ & $48.97^{b}$ & 5.69 & 0.5597 & 0.0096 & 0.2056 \\
\hline GE retention (kcal/chick) & $4,716.73$ & $4,903.51$ & $4,666.11$ & $4,494.65$ & 118.23 & $4,688.88$ & $4,701.62$ & 82.96 & 0.1493 & 0.9160 & 0.3013 \\
\hline
\end{tabular}

$\mathrm{ME}$, metabolizable energy; $\mathrm{CP}$, crude protein; SEM, standard error of the means; GE, gross energy

$a, b$ Means with different superscripts within each row indicate differences $(p<0.05)$. 
Table 7. Retention efficiency of CP and GE in the whole-body of Mexican Creole chickens of 12 weeks of age fed diets with different concentrations of ME and CP

\begin{tabular}{lcccccc}
\hline \multirow{2}{*}{ Variable } & \multicolumn{3}{c}{ ME/CP concentrations of diets } & \multirow{2}{*}{ SEM } & \multirow{2}{*}{ p-value } \\
\cline { 2 - 4 } & $\mathbf{3 , 0 0 0 / 2 0}$ & $\mathbf{2 , 8 5 0 / 1 9}$ & $\mathbf{2 , 7 0 0 / 1 8}$ & $\mathbf{2 , 5 5 0 / 1 7}$ & & 2.48 \\
CP retention efficiency (\%) & $25.46^{\mathrm{b}}$ & $34.18^{\mathrm{a}}$ & $36.75^{\mathrm{a}}$ & $33.97^{\mathrm{a}}$ & 0.0032 \\
GE retention efficiency (\%) & $29.77^{\mathrm{a}}$ & $29.75^{\mathrm{a}}$ & $26.58^{\mathrm{b}}$ & $25.22^{\mathrm{b}}$ & 0.74 & 0.0005 \\
Nitrogen excretion (g/chick) & 88.42 & 85.50 & 86.89 & 81.06 & 1.94 & 0.0961 \\
\hline
\end{tabular}

ME, metabolizable energy; $C P$, crude protein; SEM, standard error of the means; GE, gross energy.

${ }^{a, b}$ Means with different superscripts within each row indicate differences $(p<0.05)$.

The present investigation showed that BWG of Mexican Creole chickens from hatching to 12 weeks of age was not affected by decreasing of ME and CP in the diet from 3,000 $\mathrm{kcal} \mathrm{ME} / \mathrm{kg}$ and $20 \% \mathrm{CP}$ to $2,550 \mathrm{kcal} \mathrm{ME} / \mathrm{kg}$ and $17 \% \mathrm{CP}$, keeping the levels of essential amino acids constant. However, FI and feed conversion increased. These results are consistent with other investigations $[5,16]$, where it was found that broilers fed with diets low in ME and CP can maintain BWG because FI increased. Likewise, Leeson and Summers [4] reported that by reducing ME in commercial poultry diets, FI increased to meet the chicken energy needs, which would explain the differences in feed conversion observed in this work.

Carcass yield was not affected by the experimental diets. In general, males showed higher weights and carcass yields than females. Probably these results are due to the constant levels of essential amino acids in the diets, particularly lysine and methionine, because these two amino acids are mainly involved in the formation of muscle tissue $[17,18]$.

The diets with a lower concentration of $\mathrm{ME}$ and $\mathrm{CP}$ allowed include more fibrous ingredients. There are some investigations that showed that moderate fiber inclusion in diets improves the development and functions of the gizzard [19, 20], increases the secretion of $\mathrm{HCl}$, bile acids and enzymatic secretions from the pancreas [21]. This in turn improves the gastroduodenal reflux that facilitates the contact between nutrients and digestive enzymatic secretions. The improved contact increases the relative weight of crop, proventriculus and gizzard [22]. All the above mentioned may explain why chickens, fed with the diet lower in ME and $\mathrm{CP}$, showed greater relative weight of the crop, gizzard and pancreas. Mabelebele et al [23] reported that digestive organs in male chickens are heavier and longer than in females, which can result in greater production of digestive enzymes and a greater contact surface for the absorption of nutrients, and result in a higher rate of growth. In the present experiment, the females had greater relative empty weight of the proventriculus, gizzard and caeca, greater relative weight of the liver and pancreas as well as greater relative length of the small intestine and caeca. This could be due to a lower value of the denominator when the relative weight was es- timated [12,24].

The chemical composition of the whole-body of chickens did not change by effect of the diet. This was probably due to the fact that a ratio of 150 ( $\mathrm{kcal} \mathrm{ME} \mathrm{kg/ \%} \mathrm{CP)} \mathrm{was} \mathrm{kept} \mathrm{con-}$ stant in the experimental diets. It has been observed that increasing this ratio $(>172)$ induces a higher rate of lipogenesis, which changes the chemical composition of the chicken body [5]. With the diet 3000/20, less CP retention was observed. This is consistent with Belloir et al [25], who reported lower retention of $\mathrm{N}$ in the body of male Ross PM3 chickens, when they were fed with diets with high CP content. In the present study, probably the energy of the diet was higher than that required by the birds, which resulted in a lower FI. In agreement with Leeson and Summers [4], birds fed the 3,000/20 diet consumed fewer grams of CP compared to the others.

Females had lower retention of $\mathrm{CP}$ and fat, due to the fact that they had a lower live weight compared to males. That is, the content of $\mathrm{CP}$ and body fat varied due to the differences in body weight that result from the sexual dimorphism of chickens [26]. Some research reported that females had lower rates of CP deposition and higher fat deposition [27].

Chickens fed diets 2,700/18 and 2,550/17 had lower GE retention efficiency, which could be interpreted as a better balance of ME, CP, and amino acids, that decreased the availability of nutrients for storage via the catabolism of amino acids to form glycogen [25]. The CP retention efficiency was lower in chickens fed diet 3,000/20, which agrees with Belloir et al [25], who observed lower $\mathrm{N}$ retention with diets high in $\mathrm{CP}$ due to deamination of amino acids, lower $\mathrm{CP}$ retention efficiency, and increasing $\mathrm{N}$ excretion [4].

In conclusion, it is possible to feed the Mexican Creole chickens from hatching to 12 weeks of age with a diet of 2,550 $\mathrm{kcal} \mathrm{ME} / \mathrm{kg}$ and $17 \% \mathrm{CP}$, without affecting BWG, and carcass yield, but improving the retention and retention efficiency of $\mathrm{CP}$. These $\mathrm{ME}$ and $\mathrm{CP}$ values can be used as a reference point for the design of diets for this genotype of birds.

\section{CONFLICT OF INTEREST}

We certify that there is no conflict of interest with any financial 
organization regarding the material discussed in the manuscript. Chan-Díaz DJ is an employee of Trouw Nutrition Mexico.

\section{ACKNOWLEDGMENTS}

Matus-Aragón, Miguel Ángel thanks the National Council of Science and Technology of Mexico (CONACyT), for the financial support provided toward his $\mathrm{PhD}$ studies, and also to Dr. John J. Brejda for the English proofreading.

\section{REFERENCES}

1. Mata-Estrada A, González-Cerón F, Pro-Martínez A, et al. Comparison of four nonlinear growth models in Creole chickens of Mexico. Poult Sci 2020;99:1995-2000. https://doi. org/10.1016/j.psj.2019.11.031

2. Padhi MK. Importance of Indigenous Breeds of Chicken for Rural Economy and Their Improvements for Higher Production Performance. Scientifica 2016;2016:Article ID 2604685. https://doi.org/10.1155/2016/2604685

3. Perween S, Kumar K, Chandramoni, et al. Effect of feeding different dietary levels of energy and protein on growth performance and immune status of Vanaraja chicken in the tropic. Vet World 2016;9:893-9. https://doi.org/10.14202/ vetworld.2016.893-899

4. Leeson S, Summers JD. Nutrition of the chicken. 4th ed. Guelph, Ontario, Canada: University book; 2001.

5. Aletor VA, Hamid II, Nieß E, Pfeffer E. Low-protein amino acid-supplemented diets in broiler chickens: effects on performance, carcass characteristics, whole-body composition and efficiencies of nutrient utilisation. J Sci Food Agric 2000;80: 547-54. https://doi.org/10.1002/(SICI)1097-0010(200004)80: 5<547::AID-JSFA531>3.0.CO;2-C

6. Bregendahl K, Sell JL, Zimmerman DR. Effect of low-protein diets on growth performance and body composition of broiler chicks. Poult Sci 2002;81:1156-67. https://doi.org/10.1093/ ps/81.8.1156

7. Van Harn J, Dijkslag MA, Van Krimpen MM. Effect of low protein diets supplemented with free amino acids on growth performance, slaughter yield, litter quality, and footpad lesions of male broilers. Poult Sci 2019;98:4868-77. https://doi.org/ $10.3382 / \mathrm{ps} / \mathrm{pez} 229$

8. Segura-Correa JC, Sarmiento-Franco L, Magaña-Monforte JG, Santos-Ricalde R. Productive performance of Creole chickens and their crosses raised under semi-intensive management conditions in Yucatan, Mexico. Br Poult Sci 2004;45:342-5. https://doi.org/10.1080/00071660410001730 833

9. Storey ML. Web-punching of day-old ducklings as a means of identification. Poult Sci 1985;64:423-4. https://doi.org/10. 3382/ps.0640423
10. National Research Council (NRC). Nutrient requirements of poultry. Washington, DC, USA: National Academies Press; 1994.

11.Official Mexican Standard, NOM-033-SAG/ZOO-2014. Methods to kill domestic and wild animals. Mexico: Official Diary of the Federation; 2015.

12.Mera-Zúñiga F, Pro-Martínez A, Zamora-Natera JF, et al. Soybean meal substitution by dehulled lupine (Lupinus angustifolius) with enzymes in broiler diets. Asian-Australas J Anim Sci 2019;32:564-73. https://doi.org/10.5713/ajas.18.0340

13.AOAC. Official methods of analysis of the Association of Official Analytical Chemists. 15th ed. Washington, DC, USA: Association of Official Analytical Chemists; 1990.

14.SAS Institute Inc. Base SAS 9.4 procedures guide. Cary, NC, USA: SAS Institute Inc; 2013.

15. Kenward-Roger [internet]. SAS/STAT; The GLIMMIX Procedure: Kenward-Roger Degrees of Freedom Approximation; 1997 [cited 2020 Jul 15]. Available from: https://documen tation.sas.com/?docsetId=statug\&docset Target=statug _ glimmix_details40.htm\%3Flocale\&docsetVersion=14.2\&lo cale $=$ es

16. Kamran Z, Sarwar M, Nisa M, et al. Effect of low-protein diets having constant energy-to-protein ratio on performance and carcass characteristics of broiler chickens from one to thirty-five days of age. Poult Sci 2008;87:468-74. https://doi. org/10.3382/ps.2007-00180

17.Si J, Fritts CA, Burnham DJ, Waldroup PW. Relationship of dietary lysine level to the concentration of all essential amino acids in broiler diets. Poult Sci 2001;80:1472-9. https://doi. org/10.1093/ps/80.10.1472

18. Vieira SL, Lemme A, Goldenberg DB, Brugalli, I. Responses of growing broilers to diets with increased sulfur amino acids to lysine ratios at two dietary protein levels. Poult Sci 2004; 83:1307-13. https://doi.org/10.1093/ps/83.8.1307

19. González-Alvarado JM, Jiménez-Moreno E, González-Sánchez D, Lázaro R, Mateos GG. Effect of inclusion of oat hulls and sugar beet pulp in the diet on productive performance and digestive traits of broilers from 1 to 42 days of age. Anim Feed Sci Technol 2010;162:37-46. https://doi.org/10.1016/ j.anifeedsci.2010.08.010

20. Hetland H, Svihus B, Krogdahl Å. Effects of oat hulls and wood shavings on digestion in broilers and layers fed diets based on whole or ground wheat. Br Poult Sci 2003;44:27582. https://doi.org/10.1080/0007166031000124595

21.Svihus B, Juvik E, Hetland H, Krogdahl Å. Causes for improvement in nutritive value of broiler chicken diets with whole wheat instead of ground wheat. Br Poult Sci 2004;45:55-60. https://doi.org/10.1080/00071660410001668860

22. Brenes A, Marquardt RR, Guenter W, Viveros A. Effect of enzyme addition on the performance and gastrointestinal tract size of chicks fed lupin seed and their fractions. Poult Sci 2002;81:670-8. https://doi.org/10.1093/ps/81.5.670 
23. Mabelebele M, Norris D, Brown D, Ginindza MM, Ngambi JW. Breed and sex differences in the gross anatomy, digesta $\mathrm{pH}$ and histomorphology of the gastrointestinal tract of gallus gallus domesticus. Braz J Poult Sci 2017;19:339-46. https://doi.org/10.1590/1806-9061-2016-0275

24.Nitsan Z, Dunnington EA, Siegel PB. Organ growth and digestive enzyme levels to fifteen days of age in lines of chickens differing in body weight. Poult Sci 1991;70:20408. https://doi.org/10.3382/ps.0702040

25. Belloir P, Meda B, Lambert W, et al. Reducing the CP content in broiler feeds: impact on animal performance, meat quality and nitrogen utilization. Animal 2017;11:1881-9. https://doi. org/10.1017/S1751731117000660

26. Da Costa MJ, Zaragoza-Santacruz S, Frost TJ, Halley J, Pesti GM. Straight-run vs. sex separate rearing for 2 broiler genetic lines Part 1: Live production parameters, carcass yield, and feeding behavior. Poult Sci 2017;96:2641-61. https://doi.org/ 10.3382/ps/pex035

27. Brainer MMA, Rabello CBV, Santos MJB, et al. Prediction of the metabolizable energy requirements of free-range laying hens. J Anim Sci 2016;94:117-24. https://doi.org/10.2527/ jas.2015-9272 